\title{
Comparative Analysis of Defense Responses in Chocolate Spot-Resistant and -Susceptible Faba Bean (Vicia faba) Cultivars Following Infection by the Necro- trophic Fungus Botrytis fabae
}

\author{
Mahmoud H. El-Komy* \\ Department of Plant Protection, College of Food and Agricultural Sciences, King Saud University, Kingdom of Saudi Arabia \\ Plant Pathology Institute, Agriculture Research Center (ARC), Egypt
}

(Received on June 3, 2014; Revised on July 30, 2014; Accepted on August 5, 2014)

In this study, resistance responses were investigated during the interaction of Botrytis fabae with two faba bean cultivars expressing different levels of resistance against this pathogen, Nubaria (resistant) and Giza 40 (susceptible). Disease severity was assessed on leaves using a rating scale from 1 to 9. Accumulation levels of reactive oxygen species (ROS), lipid peroxidation and antioxidant enzymes (superoxide dismutase, catalase and ascorbate peroxidase) were measured in leaf tissues at different times of infection. The expression profiles of two pathogenesis-related proteins (PRPs) encoded by the genes $P R-1$ and $\beta$-1,3-glucanase were also investigated using reverse transcription RT-PCR analysis. The accumulation of these defense responses was induced significantly in both cultivars upon infection with B. fabae compared with un-inoculated controls. The resistant cultivar showed weaker necrotic symptom expression, less ROS accumulation, a lower rate of lipid peroxidation and higher activity of the enzymatic ROS scavenging system compared with susceptible cultivar. Interestingly, ROS accumulated rapidly in the resistant leaf tissues and peaked during the early stages of infection, whereas accumulation was stronger and more intense in the susceptible tissues in later stages. Moreover, the response of the resistant cultivar to infection was earlier and stronger, exhibiting high transcript accumulation of the $P R$ genes. These results indicated that the induction of oxidant/antioxidant responses and the accumulation of PRPs are part of the faba bean defense mechanism against the necrotrophic fungus $B$. fabae with a different intensity and timing of induction, depending on the resistance levels.

\footnotetext{
*Corresponding author.

Phone) +96614678428, FAX) +96614678423

E-mail)malkomy@ksu.edu.sa
}

Keywords : antioxidant enzymes, chocolate spot, defense responses, PR-proteins, reactive oxygen species, Vicia faba

Chocolate spot, which is incited by the necrotrophic plant pathogen Botrytis fabae Sard., is one of the devastating diseases of Faba bean (FB) (Vicia faba L.) production worldwide (Rhaïem et al., 2002; Torres et al., 2004), including Egypt (Abo-Hegazy et al., 2012; Abou-Zeid et al., 1990; Khalil and Harrison, 1981). The pathogen attacks all of the aboveground parts of the FB plant, thereby causing chocolate-colored lesions that may spread quickly around the infection site, killing the tissue above the lesion (Bouhassan et al., 2004). In Egypt, yield losses exceed 20-25\% (Khalil et al., 1993) and may reach 100\% under severe epidemic conditions (Bouhassan et al., 2004; Torres et al., 2004). The deployment of resistant FB varieties is an efficient strategy for controlling the disease and promoting the development of sustainable agriculture (Bouhassan et al., 2004; Rhaïem et al., 2002). However, only limited studies exist on the defense responses of the $\mathrm{FB} \times B$. fabae interaction (Sillero et al., 2010).

Plants defend themselves against fungal infection through the activation of complex defense responses (Dangl and Jones, 2001). One of the earliest these responses is the rapid generation of reactive oxygen species (ROS), which includes superoxide anion $\left(\mathrm{O}_{2}^{-}\right)$, hydroxyl radical $(\mathrm{OH} \bullet)$ and hydrogen peroxide $\left(\mathrm{H}_{2} \mathrm{O}_{2}\right)$ (Patykowski and Urbanek, 2003). There are numerous studies demonstrating the production of these free radicals in plants as an initial response to microorganisms, both pathogenic and non-pathogenic (Bolwell et al., 2002; Garcia-Limones et al., 2002; Gill and Tuteja, 2010). ROS may have multiple effects on defense responses, including direct antimicrobial action, lignin biosynthesis, phytoalexin production and the triggering of systemic acquired resistance (Bradely et al., 1992; Lamd 
and Dixon, 1997; Laloi et al., 2004; Peng and Kuć, 1992). Nevertheless, the excess ROS causes oxidative damage, leads to lipid peroxidation and damages macromolecules such as pigments, proteins, nucleic acids and lipids (Apel and Hirt, 2004). To limit oxidative damage, plants have a defense antioxidative system to modulate the cytotoxic effects of these free radicals, which include enzymes such as superoxide dismutase (SOD), peroxidase (POX), ascorbate peroxidase (APX) and catalase (CAT) (Mittler, 2002). However, the role of ROS in the defense mechanism against necrotrophic fungi (e.g., Botrytis spp.) remains controversial (Asselbergh et al., 2007). Some studies have demonstrated a positive effect of ROS on plant resistance (Malolepsza and Urbanek, 2000; Unger et al., 2005). In contrast, other studies have demonstrated that the level of ROS accumulation in plant tissues was proportionally correlated with the aggressiveness of the necrotrophic pathogens (Govrin and Levine, 2000; Mayer et al., 2001; von Tiedemann, 1997).

Furthermore, in different plant $\times$ pathogen interactions, the defense response has been associated with the accumulation of pathogenesis-related proteins (PRs) genes, which are plant species-specific proteins, and their expression is highly associated with enhanced resistance (van Loon, 1997; van Loon and van Strien, 1999). In addition, most PRs possess antimicrobial activities in vitro through hydrolytic activities on cell walls and contact toxicity (van Loon et al., 2006). These proteins have attracted much attention and have become very important resources in the genetic engineering of crop plants for disease resistance (van Loon et al., 2006). PR proteins, which are grouped into seventeen families, show different serological relationships and biological activities (Park et al., 2004; van Loon et al., 2006). The $P R-1$ represents a group of PR gene families (Sarowar et al., 2005) whose role in disease resistance is often associated with antifungal properties such as the hydrolysis of fungal cell walls (van Loon and van Strien, 1999; van Loon et al., 2006). $P R-1$ is widely thought to be used as marker gene for systemic acquired resistance in many plant species (Sarowar et al., 2005). PR-2 protein, which has $\beta-1,3-$ glucanase activity, can inhibit the growth of a fungus either directly by degrading fungal cell walls (Mauch et al., 1988) or by releasing short glucan fragments from pathogen cell walls, which can also act as signal molecules to stimulate further plant defense responses (Ebel and Cosio, 1994). The involvement of PR genes in FB plants after pathogen attack has been previously demonstrated (Attia et al., 2007; Cheng et al., 2012; Rauscher et al., 1999). However, no data are available regarding the differential induction of the above mentioned $P R$ genes in FB cultivars possessing dif- ferent levels of resistance against $B$. fabae.

The aim of this study was to identify reliable biochemical and molecular indicators of FB resistance to chocolate spot. In this regard, the disease severity and the accumulation levels of $\mathrm{H}_{2} \mathrm{O}_{2}$, lipid peroxidation and antioxidant enzymes (SOD, CAT, POX), as well as the expression of pathogenesis-related $P R-1(V f P R 1)$ and $\beta$-1,3-glucanases (VfPR2) genes were investigated in two FB cultivars, Nubaria and Giza 40, which are resistant and susceptible, respectively, to chocolate spot during the infection process of $B$. fabae.

\section{Materials and Methods}

Fungal culture and inoculum preparation. An aggressive single-spored $B$. fabae isolate recovered from a diseased FB plant exhibiting symptoms of chocolate spot disease was used in this study. The fungal isolate was grown on potato dextrose agar plates and incubated at $25^{\circ} \mathrm{C}$ for 7-10 days. To induce sporulation, the fungal culture was transferred to FB leaf extract medium as described by Leach and Moore (1966) for 10 days at $20-22^{\circ} \mathrm{C}$. Conidia were collected by washing plates with $4-5 \mathrm{ml}$ of sterile distilled water, and the resulting spore suspension was adjusted to $3 \times 10^{6}$ conidia/ml using a hemocytometer (Bouhassan et al., 2004).

Faba bean plants and inoculation. Two FB cultivars, Nubaria (resistant) and Giza 40 (susceptible), were chosen for this study because of their respective resistance and susceptibility to chocolate spot disease in a preliminary screen. The FB cultivars were obtained from the Field Crop Research Institute, Agricultural Research Center, Giza, Egypt. The FB seeds were planted in $15 \mathrm{~cm}$-diameter pots filled with arable soil, peat moss and sand (1:1:1; v:v:v) and kept in an environmentally controlled greenhouse at $24 \pm 2^{\circ} \mathrm{C}$ with a 16-h photoperiod. The germinated seedlings were thinned to one plant per pot. At the beginning of the flowering stage (7-week-old plants), FB plants were individually spray-inoculated to run-off with a conidial suspension of $B$. fabae $(25 \mathrm{ml} /$ plant) supplemented with $0.01 \%$ Tween 20 . After inoculation, the plants were placed in a moist chamber in a greenhouse at $24 \pm 2^{\circ} \mathrm{C}$ with a 16 -h photoperiod.

Evaluation of disease severity. Twenty plants from each cultivar were rated individually for disease symptoms on the leaves at 48, 72 and $120 \mathrm{~h}$ post inoculation (hpi) using a qualitative scale of 1-9, where 1 indicates no visible symptoms and 9 represents disease covering more than $80 \%$ of the foliar tissue (ICARDA, 1986). The disease severity (DS) for each plant was calculated as follows: 
$\mathrm{DS}=\left\{\sum_{i=0}^{n}(n \times b)\right\} \times 100 / T \times N$ where $b$ is the infection rating and $n$ is the number of leaves with that rating, $N$ is the maximum number of the rating used on the scale (9) and $T$ is the total number of leaves. Based on the severity values ratings over time, the area under disease progress curve (AUDPC) was calculated as follows: AUDPC $=\sum_{i=1}^{n}\left[\left(y_{i}+y_{i+1}\right) / 2\right]\left[x_{i+1}+x_{i}\right]$, where $i=1,2,3, \ldots . . \mathrm{n}-1, y_{\mathrm{i}}$ is the disease severity, and $x_{\mathrm{i}}$ is the time of $\mathrm{i}^{\text {th }}$ rating (Shaner and Finney, 1977). Five days after inoculation, the disease symptoms were daily monitored and recorded.

\section{Plant defense response.}

Sampling procedures for plant defense response assays. Leaf samples from nodes No. 4-7 were collected separately at time points of $0,12,24,36,48,7296$ and 120 hpi and were immediately frozen in liquid nitrogen (3 FB plants per cultivar for each time interval). The samples from each plant were stored at $-80^{\circ} \mathrm{C}$ and analyzed separately to represent three biological repetitions for various analyses. The control FB plants were only treated with sterilized water.

Assay of $\mathrm{H}_{2} \mathrm{O}_{2}$ generation. Hydrogen peroxide was measured by the method discredited by Velikova et al. (2000) with minor modification. Leaf samples were homogenized in $0.1 \%$ trichloroacetic acid (TCA) in ratio of $1: 10(\mathrm{w} / \mathrm{v})$ and centrifuged at $12,000 \times g$ for $15 \mathrm{~min}$ at $4^{\circ} \mathrm{C}$. Next, the leaf extract $(0.5 \mathrm{ml})$ was added to $0.5 \mathrm{ml}$ of $10 \mathrm{mM}$ potassium phosphate buffer ( $\mathrm{pH} 7.0)$ and $1 \mathrm{ml}$ of $1 \mathrm{M}$ potassium iodide and then vortexed briefly. The absorbency of the oxidation product was measured at a wavelength of 390 nm after 5 min using a Jenway 6715 spectrophotometer (Bibby Scientific Limited, Staffordshire, UK). Hydrogen peroxide content was calculated using a standard curve prepared with known concentrations of $\mathrm{H}_{2} \mathrm{O}_{2}$ and expressed as mmole/g FW.

Determination of lipid peroxidation. Lipid peroxidation was measured in terms of malondialdehyde (MDA) content, a thiobarbituric acid reactive substance according to Heath and Packer (1968). Leaf samples were homogenized in $0.1 \%$ TCA in ratio of $1: 5(\mathrm{w} / \mathrm{v})$ and centrifuged at $12,000 \times \mathrm{g}$ for $30 \mathrm{~min}$ at $4^{\circ} \mathrm{C}$. A $1-\mathrm{ml}$ of the leaf extract was incubated with $4 \mathrm{ml}$ of $20 \%$ TCA containing $0.5 \%$ thiobarbituric acid (TBA) for $30 \mathrm{~min}$ at $95^{\circ} \mathrm{C}$. The mixture was incubated at $95^{\circ} \mathrm{C}$ for 30 minutes and then quickly cooled on ice. After centrifugation at $10,000 \times g$ for $15 \mathrm{~min}$, the absorbance of the reaction product was measured at 450,532 and $600 \mathrm{~nm}$. The level of lipid peroxidation is expressed as mmole/g FW of MDA-TBA complex formed using an extinction coefficient of $155 / \mathrm{mM} / \mathrm{cm}$.
Antioxidant enzyme assays

Preparation of enzyme extracts. FB leaf samples were immersed in liquid nitrogen and ground into a powder using a mortar and pestle. Soluble proteins were extracted by re-suspending the powder in four volumes of $100 \mathrm{mM}$ phosphate buffer ( $\mathrm{pH} 7.0$ ), containing $100 \mathrm{mM}$ Na-EDTA and $1 \%(\mathrm{w} / \mathrm{v})$ polyvinylpyrrolidone (PVP). After centrifugation at $10,000 \times \mathrm{g}$ for $30 \mathrm{~min}$ at $4^{\circ} \mathrm{C}$, the supernatant was collected and stored at $-80^{\circ} \mathrm{C}$ for further analysis of enzyme activity (Velikova et al., 2000). Protein concentrations were measured according to the Bradford method (1976) with bovine serum albumin as the standard.

Superoxide dismutase (SOD) activity. SOD activity was assayed by measuring its ability to inhibit the photochemical reduction of nitro blue tetrazolium (NBT) chloride according to the methods of Beauchamp and Fridovich (1971) with minor modification. The reaction mixture (1.5 $\mathrm{ml}$ ) was set up in a test tube containing $50 \mathrm{mM}$ potassium phosphate buffer ( $\mathrm{pH}$ 7.8), $0.05 \mathrm{mM}$ EDTA, $13 \mathrm{mM}$ methionine, $75 \mu \mathrm{M}$ nitro blue tetrazolium (NBT), $100 \mu 1$ enzyme extract and $20 \mu \mathrm{M}$ riboflavine. The tubes were kept under two $15-\mathrm{W}$ fluorescent lamps for $15 \mathrm{~min}$ at $25^{\circ} \mathrm{C}$, followed by their transfer to the dark for $15 \mathrm{~min}$. Absorbance at 560 $\mathrm{nm}$ was then measured. The amount of SOD that causes a $50 \%$ inhibition of NBT reduction was defined as 1 unit, and the SOD activity was expressed as nkat/mg protein.

Catalase (CAT) activity. CAT activity was assayed by measuring the rate of disappearance of $\mathrm{H}_{2} \mathrm{O}_{2}$ at $240 \mathrm{~nm}$ according to the methods of Cakmak and Marschner (1992) with minor modification. The $1-\mathrm{ml}$ reaction mixture consisted of $50 \mu \mathrm{l}$ enzyme extract, $25 \mathrm{mM}$ phosphate buffer $(\mathrm{pH}$ 7.0), and $10 \mathrm{mM} \mathrm{H}_{2} \mathrm{O}_{2}$ diluted in buffer, which initiated the reaction. One unit was defined as the amount of enzyme necessary to decompose $1 \mu \mathrm{mol} / \mathrm{min}_{2} \mathrm{O}_{2}$ under the conditions of the assay. CAT activity was expressed as nkat $\mathrm{mg}^{-1}$ protein.

Ascorbate peroxidase (APX) activity. APX activity was assayed according to the method of Nakano and Asada (2001) with minor modification. The reaction mixture (1 $\mathrm{ml}$ ) consisted of $25 \mathrm{mM}$ phosphate buffer $\mathrm{pH} 7.0$ (containing $0.1 \mathrm{mM}$ EDTA), $0.25 \mathrm{mM}$ ascorbic acid and $100 \mu \mathrm{l}$ enzyme extract. The reaction was initiated by the addition of $10 \mu \mathrm{l}$ of $10 \mathrm{mM} \mathrm{H}_{2} \mathrm{O}_{2}$. Decreased absorbance was observed $1 \mathrm{~min}$ after the addition of enzyme extract at $290 \mathrm{~nm}$. One unit was defined as a change in absorbance of 0.1 under the conditions of the assay. APX activity was expressed as nkat/mg protein. 
Expression analysis of PR proteins genes.

RNA extraction. Total RNA was extracted using TRIzol reagent (Life Technologies, Invitrogen, Carlsbad, CA, USA) according to the manufacturer's instructions. Leaf tissues $(\approx 100 \mathrm{mg})$ were ground in liquid nitrogen and homogenized directly in $1 \mathrm{~mL}$ of TRIzol reagent solution. The homogenized sample was centrifuged at $8,000 \times g$ for $5 \mathrm{~min}$ at $4^{\circ} \mathrm{C}$. The upper aqueous layer was collected and transferred to a new 1.5 micro-centrifuge tube to which $300 \mu \mathrm{l}$ of chloroform was added, followed by mixing using a vortex. The mixture was centrifuged at $10,000 \times g$ for 15 $\min$ at $4^{\circ} \mathrm{C}$ to separate the phases. The RNA was then precipitated by mixing the aqueous phase with $1000 \mu \mathrm{l}$ of isopropanol, and the tubes were incubated at $-20^{\circ} \mathrm{C}$ overnight. To pellet the RNA, the tubes were centrifuged at 10,000 $\times g$ for $10 \mathrm{~min}$ at $4^{\circ} \mathrm{C}$. The supernatant was removed, and the pellet was washed with $500 \mu \mathrm{l}$ of $75 \%$ ethanol and centrifuged at $10,000 \times g$ for $10 \mathrm{~min}$ at $4^{\circ} \mathrm{C}$. The RNA pellet was dried at room temperature and then dissolved in $100 \mu \mathrm{l}$ RNase-free water. Extracted RNA was treated with DNase (Ambion). The RNA was quantified spectrophotometrically, and the RNA concentration was adjusted to $50 \mathrm{ng} / \mu \mathrm{l}$ and stored at $-80^{\circ} \mathrm{C}$ for further use.

Reverse-transcription PCR analysis (RT-PCR). The expression patterns of pathogenesis-related $P R-1(V f P R 1)$ and $\beta$-1,3-glucanases (VfPR2) genes were analyzed by RT-PCR analysis. The forward and reverse primers for the selected genes are shown in Table 1 (Chang et al., 2012). Briefly, first strand cDNA was prepared from $2 \mu \mathrm{g}$ of mixed stage total RNA primed with oligo-dT using a ProtoScript ${ }^{\circledR}$ First Strand cDNA Synthesis Kit (New England Biolabs) according to the manufacturer's protocol. All PCR reactions were carried out with $0.5 \mu \mathrm{l}$ cDNA, $2.5 \mu \mathrm{l} 10 \times$ PCR buffer with $\mathrm{MgCl}_{2}, 0.5 \mu \mathrm{l} 2 \mathrm{mM}$ dNTPs, $1 \mu \mathrm{l} 10 \mu \mathrm{M}$ of each primer, $0.3 \mu \mathrm{Taq}$ DNA polymerase and RNase-free water in a final volume of $25 \mu \mathrm{l}$. In the negative control cDNA was replaced by RNase-free water. Reactions were conducted in a Techne TC-412 thermocycler (Barloworld Scientific Ltd, United Kingdom) under the following conditions: an initial 5 min denaturation at $94^{\circ} \mathrm{C}$, followed by 35 cycles of PCR $\left(94^{\circ} \mathrm{C}, 30 \mathrm{~s} ; 55^{\circ} \mathrm{C}, 30 \mathrm{~s}\right.$; and $\left.72^{\circ} \mathrm{C}, 1 \mathrm{~min}\right)$, and a final extension period at $72^{\circ} \mathrm{C}$ for $7 \mathrm{~min}$. The elongation factor 1-alpha $(V f E L F 1 A)$ gene was amplified for 25 cycles and used as a reference gene. The PCR products were analyzed by electrophoresis in $1.5 \%$ agarose ethidium bromide gels.

Data analysis. The statistical analyses were performed using the SAS software system (SAS Institute Inc., 2003). The data were statistically analyzed in a factorial model of a completely randomized experimental design. For the evaluation of disease severity, the factorial model was $2 \times 3$, consisting of two FB cultivars and three evaluation times (48, 72 and $120 \mathrm{hpi})$ with 20 replicates per treatment. For the determination of $\mathrm{H}_{2} \mathrm{O}_{2}$ and MDA concentrations as well as the SOD, CAT, and APX activity measurements, the factorial model was $2 \times 2 \times 6$, consisting of two $\mathrm{FB}$ cultivars, un-inoculated or B. fabae-inoculated plants, and eight sampling times $(0,12,24,36,48,72,96$ and 120 hpi) with 3 replicates per treatment. All experiments were conducted twice for reproducibility. Levene's test was used to check the data for homogeneity of variance and indicated that the data of the two repeats could be pooled into one analysis (Gomez and Gomez, 1984). Analyses of variances (ANOVAs) were performed for all data sets. All data are presented as means, and the statistical significance was indicated at $P<0.05$. Standard deviations were calculated in Microsoft Excel 2003.

\section{Results}

Greenhouse evaluation. The factorial analysis of variance revealed significant effects for FB cultivars, evaluation time and their interaction on the chocolate spot severity $(P$ $<0.001$ ) (Table 2). The severity of infection was expressed as the AUDPC (Table 3). The AUDPC values increased over time for both cultivars. However, the AUDPC values for the resistant cultivar Nubaria were significantly lower than those for the susceptible cultivar Giza 40. Disease symptoms were observed on susceptible plants as necrotic

Table 1. Primers used in RT-PCR analysis to amplify the genes encoding the selected PR proteins (f-Forward, r-Reverse)

\begin{tabular}{lllc}
\hline Gene & Primer sequence $\left(5^{\prime}-3^{\prime}\right)$ & Target gene & Amplicon size (bp) \\
\hline VfPR $1-f$ & CAGTGGTGACATAACAGGAGCAG & $P R-1$ & 509 \\
VfPR $1-r$ & CATCCAACCCGAACCGAAT & & 996 \\
VfPR $2-f$ & CCAATGGGTACAAAGAAACG & $\beta-1,3$-glucanase & 1,599 \\
VfPR $2-r$ & AAACCAAGTAACCAATGAAAGG & & elongation factor 1-alpha \\
VfELF 1 - $f$ & GTGAAGCCCGGTATGCTTGT & & \\
VfELF $1 A-r$ & CTTGAGATCCTTGACTGCAACATT & & \\
\hline
\end{tabular}


Table 2. Analysis of variance of the effects of FB cultivars and evaluation time for chocolate spot severity

\begin{tabular}{lcc}
\hline Sources of variation & $\mathrm{df}^{\mathrm{a}}$ & $F$ value \\
\hline Cultivar & 1 & $6409.64^{* * *}$ \\
Evaluation time & 2 & $1256.78^{* * *}$ \\
Cultivar $\times$ Evaluation time & 2 & $392.33^{* * *}$ \\
\hline
\end{tabular}

$\mathrm{df}^{\mathrm{a}}=$ degrees of freedom.

${ }^{* * *}$ Significant at 0.001 level of probability.

Table 3. Progress of chocolate spot severity expressed as area under disease progress curve (AUDPC) for two FB cultivars inoculated with a single virulent isolate of $B$. fabae at different evaluation times after inoculation using whole plant assays

\begin{tabular}{|c|c|c|c|c|c|}
\hline \multirow{2}{*}{$\begin{array}{c}\text { FB } \\
\text { cultivars }\end{array}$} & \multicolumn{3}{|c|}{ Evaluations (days after inoculation) } & \multirow{2}{*}{\multicolumn{2}{|c|}{$\mathrm{M}^{\mathrm{a}}$}} \\
\hline & 2 & 3 & 5 & & \\
\hline Nubaria & *77.7 & 86.9 & 101.5 & $88.7 \mathrm{~B}$ & Resistant \\
\hline Giza 40 & 117.5 & 157.8 & 201.5 & $159 \mathrm{~A}$ & Susceptible \\
\hline $\mathrm{M}^{\mathrm{b}}$ & $97.6 \mathrm{C}$ & $122.4 \mathrm{~b}$ & $151.5 \mathrm{a}$ & & \\
\hline
\end{tabular}

${ }^{*}$ Mean values are average of two experiments with 20 plans for each cultivar per experiment

$\mathrm{M}^{\mathrm{a}}=$ Main effect of $\mathrm{FB}$ cultivar

$\mathrm{M}^{\mathrm{b}}=$ Main effect of evaluation time

- L.S.D D.05 $_{\text {for interaction }}=2.99$

- Values followed by different lowercase or uppercase letters indicate significant differences at $P<0.05$ according to the LSD test.

lesions (48 hpi) that developed into expanding and water soaking areas within 96-120 hpi (Fig. 1). The resistant plants showed the appearance of few and restricted necrotic spots (24 hpi), resembling HR. These spots increased in intensity and size with no significant damage to the leaf area until 120 hpi (Fig. 1).

Plant defense responses. As shown in Table 4, the effects

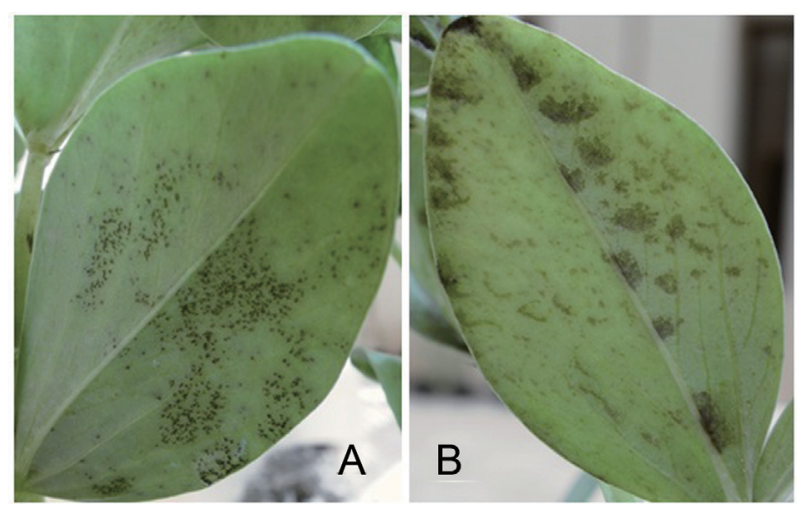

Fig. 1. FB leaves inoculated with a single virulent isolate of $B$. faba 48 hpi, showing restricted necrotic spots, resembling HR (A) observed on resistant (Nubaria) leaves that become increased in intensity and size with no significant damage to the leaf area until $120 \mathrm{hpi}$; and necrotic lesions (B) observed on susceptible (Giza 40) leaves that developed into expanding and water soaking areas within 96-120 hpi.

of the FB cultivars, plant inoculation, sampling time and their interactions were significant $(P<0.001)$ for the $\mathrm{H}_{2} \mathrm{O}_{2}$ and MDA content as well as the SOD, CAT, and APX activities.

Assay of $\mathrm{H}_{2} \mathrm{O}_{2}$ generation. Inoculation with $B$. fabae significantly enhanced the accumulation of $\mathrm{H}_{2} \mathrm{O}_{2}$ in both the resistant (Nubaria) and susceptible (Giza 40) cultivars compared with the non-inoculated controls (Table 5 and Fig. 2). In general, $\mathrm{H}_{2} \mathrm{O}_{2}$ content was significantly higher $(P<0.001)$ in the leaves of the susceptible cultivar than that of resistant ones (Table 5). The levels of $\mathrm{H}_{2} \mathrm{O}_{2}$ sharply accumulated in the inoculated resistant tissues and reached the maximum $(69.7 \mathrm{mmol} / \mathrm{g} \mathrm{FW})$ at the first $24 \mathrm{hpi}$. This level was 2.9 times higher than that of susceptible tissues, and thereafter

Table 4. Analysis of variance of the effects of FB cultivars, plant inoculation, and sampling time on the $\mathrm{H}_{2} \mathrm{O}_{2}$, and MDA content as well as the SOD, CAT, and APX activities

\begin{tabular}{|c|c|c|c|c|c|c|}
\hline \multirow{2}{*}{ Sources of variation } & \multirow{2}{*}{$\mathrm{df}^{\mathrm{a}}$} & \multicolumn{5}{|c|}{$F$ values } \\
\hline & & $\mathrm{H}_{2} \mathrm{O}_{2}$ & MAD & CAT & SOD & APX \\
\hline Cultivar & 1 & $112.70^{* * *}$ & $51.77^{* * *}$ & $164.75^{* * *}$ & $476.50^{* * *}$ & $1643.37^{* * *}$ \\
\hline Plant inoculation & 1 & $2356.82^{* * *}$ & $316.54^{* * *}$ & $1219.46^{* * *}$ & $2394.99^{* * *}$ & $4293.54^{* * *}$ \\
\hline Sampling time & 1 & $73.16^{* * *}$ & $38.64^{* * *}$ & $77.14^{* * *}$ & $411.28^{* * *}$ & $1514.05^{* * *}$ \\
\hline Cultivar $\times$ Plant inoculation & 7 & $109.27^{* * *}$ & $31.67^{* * *}$ & $48.46^{* * *}$ & $106.72^{* * *}$ & $197.1^{* * *}$ \\
\hline Cultivar $\times$ Sampling time & 7 & $124.98^{* * *}$ & $10.06^{* * *}$ & $5.27^{* * *}$ & $25.32^{* * *}$ & $75.82^{* * *}$ \\
\hline Plant inoculation $\times$ Sampling time & 7 & $107.89^{* * *}$ & $25.45^{* * *}$ & $42.93^{* * *}$ & $109.16^{* * *}$ & $186.91^{* * *}$ \\
\hline Cultivar $\times$ Plant inoculation $\times$ Sampling time & 7 & $120.84^{* * *}$ & $7.81^{* * *}$ & $5.23^{* * *}$ & $25.20^{* * *}$ & $67.87^{* * *}$ \\
\hline
\end{tabular}

$\mathrm{df}^{\mathrm{a}}=$ degrees of freedom.

${ }^{* * *}$ Significant at 0.001 level of probability. 
Table 5. $\mathrm{H}_{2} \mathrm{O}_{2}$, and MDA content as well as the SOD, CAT, and APX activities in leaves of resistant (Nubaria) and susceptible (Giza 40) FB cultivars inoculated with a single virulent isolate of $B$. fabae as compared with un-inoculated controls

\begin{tabular}{|c|c|c|c|c|c|}
\hline \multirow{2}{*}{ FB cultivars } & $\mathrm{H}_{2} \mathrm{O}_{2}$ & MAD & CAT & SOD & APX \\
\hline & \multicolumn{2}{|c|}{ Expressed as mmol/g FW } & \multicolumn{3}{|c|}{ Expressed as nkat/mg protein } \\
\hline Nubaria (inoculated) & $* 40.8 \mathrm{~B}$ & $4.4 \mathrm{~B}$ & $3.2 \mathrm{~A}$ & $18.4 \mathrm{~A}$ & $24.1 \mathrm{~A}$ \\
\hline Giza 40 (inoculated) & $51.3 \mathrm{~A}$ & $5.9 \mathrm{~A}$ & $2.4 \mathrm{~B}$ & $11.3 \mathrm{~B}$ & $15.4 \mathrm{~B}$ \\
\hline Nubaria (control) & $18.7 \mathrm{C}$ & $3.1 \mathrm{C}$ & $1.7 \mathrm{C}$ & $6.5 \mathrm{C}$ & $12.6 \mathrm{C}$ \\
\hline Giza 40 (control) & $19.8 \mathrm{C}$ & $3.2 \mathrm{C}$ & $1.5 \mathrm{C}$ & $6.2 \mathrm{C}$ & $12.4 \mathrm{C}$ \\
\hline
\end{tabular}

${ }^{*}$ Mean values are average of two experiments with three biological replicates of eight sampling times $(0,12,24,36,48,72,96$ and 120 hpi) per experiment. Values in the same column followed by different letters indicate significant differences at $P<0.05$ according to the LSD test.

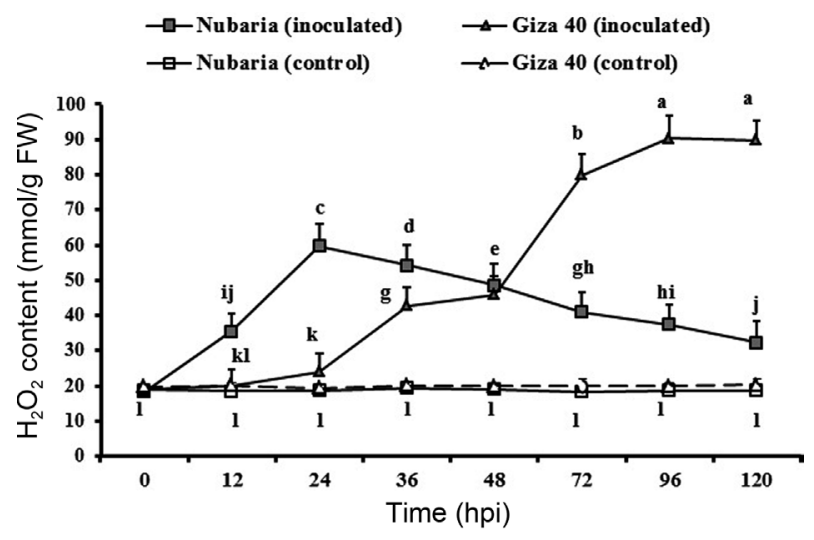

Fig. 2. Time course of the changes in $\mathrm{H}_{2} \mathrm{O}_{2}$ content (expressed as $\mathrm{mmol} / \mathrm{g} \mathrm{FW}$ ) in leaves of resistant (Nubaria) and susceptible (Giza 40) FB cultivars inoculated with $B$. fabae as compared with uninoculated controls. The experiment was conducted twice and the data for the two experiments were combined. Each value is the means of six replicates (of two experiments). Different letters indicate significant differences at $P<0.05$. Error bars represent the standard deviations of the mean.

a decline in the $\mathrm{H}_{2} \mathrm{O}_{2}$ content was observed (Fig. 2).

In the susceptible tissues, a significant induction of $\mathrm{H}_{2} \mathrm{O}_{2}$ was observed later at 36 hpi. The levels of $\mathrm{H}_{2} \mathrm{O}_{2}$ increased with time and reached its maximum $\left(90.2 \mathrm{mmol} \mathrm{g}^{-1} \mathrm{FW}\right)$ at 96 hpi, which was 2.4 times higher than that of the resistant tissues (Fig. 2). No significant changes in the $\mathrm{H}_{2} \mathrm{O}_{2}$ levels were detected with time in un-inoculated leaf tissues (Fig. 2).

Lipid peroxidation. The level of lipid peroxidation in leaf tissues was measured as the malondialdehyde (MDA) concentration. Lipid peroxidation levels were significantly higher in pathogen-inoculated leaves when compared with un-inoculated controls (Table 5 and Fig. 3). It was observed that MDA accumulation levels increased with time in the inoculated plants and were significantly higher at all-time points in Giza 40 (susceptible) than in Nubaria (resistant) (Table 5 and Fig. 3). At 96 hpi, the MDA content

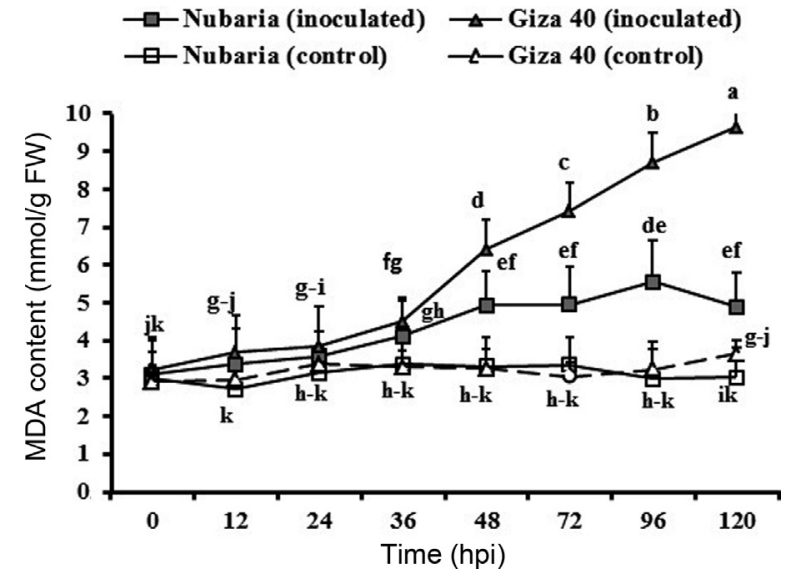

Fig. 3. Time course of the changes in lipid peroxidation levels (measured in terms of malondialdehyde (MDA) content (expressed as mmol/g FW) in leaves of resistant (Nubaria) and susceptible (Giza 40) FB cultivars inoculated with B. fabae as compared with un-inoculated controls. The experiment was conducted twice and the data for the two experiments were combined. Each value is the means of six replicates (of two experiments). Different letters indicate significant differences at $P<0.05$. Error bars represent the standard deviations of the mean.

in the susceptible tissues was $8.6 \mathrm{mmol} / \mathrm{g} \mathrm{FW}$, which was 1.6 times higher than that of the resistant tissues (Fig. 3). No significant changes in the lipid peroxidation levels were detected with time in un-inoculated leaf tissues (Fig. 3).

Superoxide dismutase (SOD) activity. Increased SOD activity in leaf tissues was observed in both cultivars after pathogen inoculation, but this increase was significantly higher in the resistant cultivar (Table 5 and Fig. 4). At 72 hpi, the enzyme activity in the resistant cultivar Nubaria was $24.4 \mathrm{nkat} / \mathrm{mg}$ protein, which was 1.5 times higher than that of the susceptible cultivar Giza 40. At this time point, SOD activity continued to increase in the resistant tissues, but it was decreasing in the susceptible tissues (Fig. 4). No significant changes in the enzyme activities were detected 


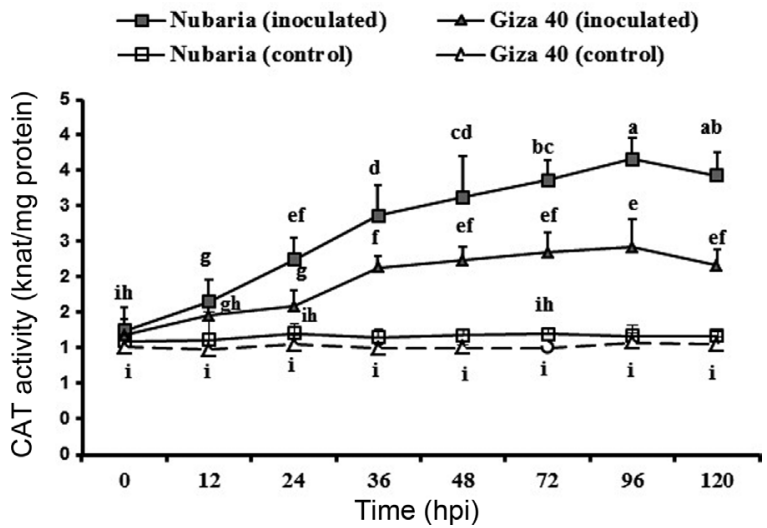

Fig. 4. Time course of the changes in CAT activity (expressed as nkat/mg protein) in leaves of resistant (Nubaria) and susceptible (Giza 40) FB cultivars inoculated with B. fabae as compared with un-inoculated controls. The experiment was conducted twice and the data for the two experiments were combined. Each value is the means of six replicates (of two experiments). Different letters indicate significant differences at $P<0.05$. Error bars represent the standard deviations of the mean.

with time in un-inoculated leaf tissues (Fig. 4).

Catalase (CAT) activity. As shown in Table 5 and Fig. 5 , the inoculated leaves of both FB cultivars showed significantly higher levels of accumulated CAT than those of un-inoculated controls. In both resistant and susceptible tissues, CAT activity increased gradually and reached its peak on 96 hpi with values of 4.2 and 2.9 nkat $\mathrm{mg}^{-1}$ protein,

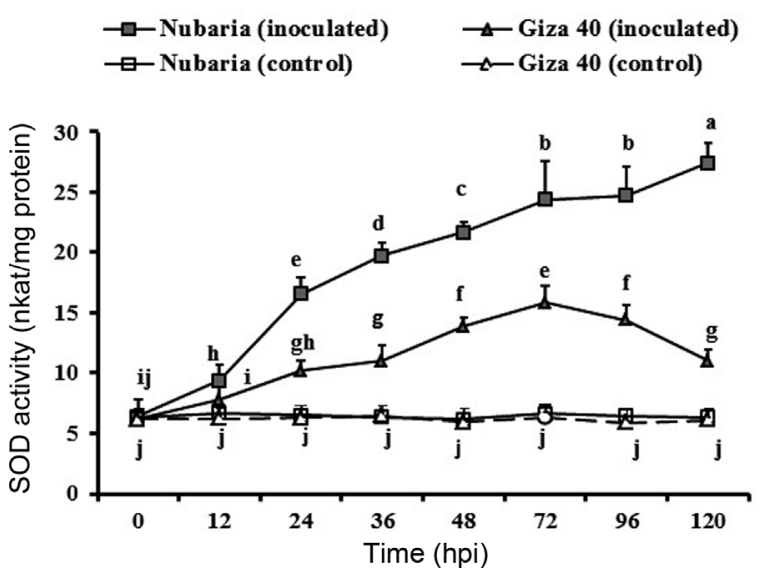

Fig. 5. Time course of the changes in SOD activity (expressed as nkat/mg protein) in leaves of resistant (Nubaria) and susceptible (Giza 40) FB cultivars inoculated with $B$. fabae as compared with un-inoculated controls. The experiment was conducted twice and the data for the two experiments were combined. Each value is the means of six replicates (of two experiments). Different letters indicate significant differences at $P<0.05$. Error bars represent the standard deviations of the mean.

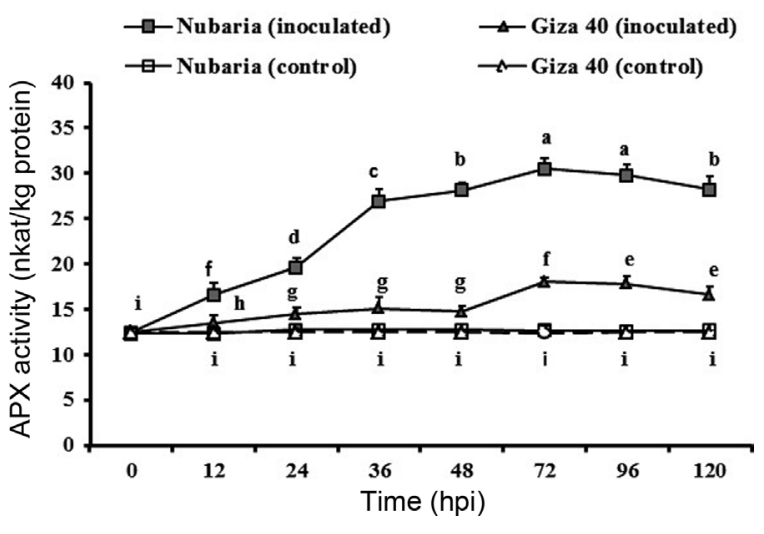

Fig. 6. Time course of the changes in APX activity (expressed as nkat/mg protein) in leaves of resistant (Nubaria) and susceptible (Giza 40) FB cultivars inoculated with $B$. fabae as compared with un-inoculated controls. The experiment was conducted twice and the data for the two experiments were combined. Each value is the means of six replicates (of two experiments). Different letters indicate significant differences at $P<0.05$. Error bars represent the standard deviations of the mean.

respectively. However, the induced levels of CAT were significantly higher in the inoculated leaves of the resistant cultivar compared to those of the susceptible cultivar at alltime points investigated (Table 5 and Fig. 5). No significant changes in the enzyme activities were detected with time in un-inoculated leaf tissues (Fig. 5).

Ascorbate peroxidase (APX) activity. As shown in Table 5 and Fig. 6, APX activity in the un-inoculated controls of each cultivar was significantly lower than that of inoculated plants. In the resistant cultivar, APX activity was higher than in the susceptible cultivar at all-time point investigated. The level of APX reached its maximum (30.5 nkat/mg protein) at $72 \mathrm{hpi}$ in the inoculated resistant tissues, which was 1.7 times higher than that of susceptible tissues at this time point. In susceptible tissues, the increase of APX activity was lower following infection. No significant changes in the enzyme activities were detected with time in un-inoculated leaf tissues (Fig. 6).

Expression analysis of PR proteins genes. As shown in Fig. 7, the expression of pathogenesis-related $P R-1(V f P R 1)$ and $\beta$-1,3-glucanase (VfPR2) genes in the leaves of the resistant Nubaria and susceptible Giza 40 cultivars in response to inoculation with $B$. $f a b a$ at different time points was compared with that of un-infected plants. The accumulation of VfPRl was observed over time in both the uninoculated and the inoculated leaves; this accumulation was greater in inoculated leaves and higher in the resistant 


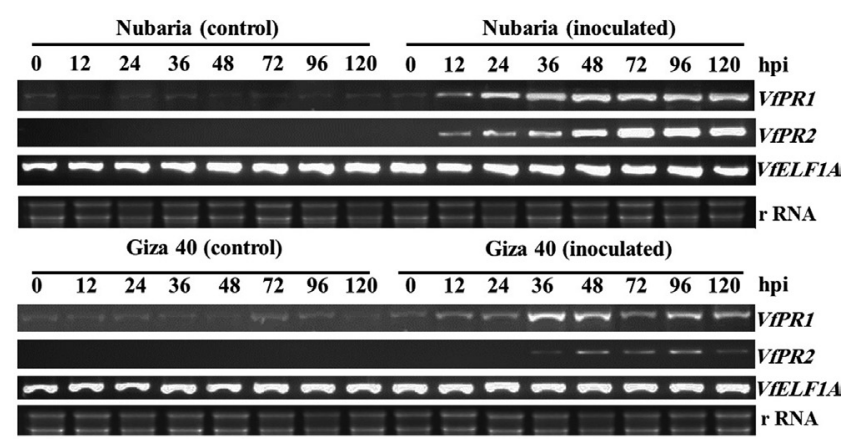

Fig. 7. Reverse-transcriptase polymerase chain reaction (RT-PCR) analysis showing expression patterns of the pathogenesis-related gene $1(V f P R 1)$ and gene $2(V f P R 2)$ in the leaf samples of resistant (Nubaria) and susceptible (Giza 40) FB cultivars at different time points after inoculation with $B$. fabae as compared with uninoculated controls. The elongation factor 1-alpha (VfELF1A) gene was used as a reference gene. The experiment was conducted twice with similar results.

cultivar compared to susceptible ones.

No transcripts encoding VfPR2 were detected over time in un-inoculated leaves and it was induced in leaves after inoculation with $B$. faba (Fig. 7). In the resistant cultivar, the levels of VfPR2 expression were detectable as early as $6 \mathrm{hpi}$, peaked at $72 \mathrm{hpi}$ and remained high for the rest of the time. $V f P R 2$ transcripts displayed a weak accumulation in the susceptible cultivar observed at 24 and $96 \mathrm{hpi}$, after which the transcript levels declined (Fig. 7).

\section{Discussion}

The management of chocolate spot using resistant faba bean (FB) cultivars is a priority strategy to control the disease, but no completely resistant cultivars have been developed so far (Sillero et al., 2010; Villegas-Fernández et al., 2009). The understanding of the biochemical and molecular mechanisms conferring resistance against $B$. fabae could provide valuable information for breeding new resistant cultivars. In the current study, the reactions of two FB cultivars expressing different levels of resistance against to $B$. fabae, Nubaria (resistant) and Giza 40 (susceptible), were investigated using whole plant assays to avoid responses induced by wounding and not associated with the infection (Bertini et al., 2003). For both cultivars, there was a significant increase in the chocolate spot severity over time. The progress of the disease symptoms evolved slowly on resistant cultivar but occurred at a much greater rate on the susceptible cultivar. However, disease severity was significantly lower for Nubaria than for Giza 40, regardless of the evaluation time. These results were in agreement with those of Abo-Hegazy et al. (2012) who showed that the Nubaria and Giza 40 FB cultivars were resistant and susceptible, respectively, to infection by $B$. fabae. The lowest levels of disease severity recorded in the leaves of Nubaria suggest that resistance events that delay tissue colonization after fungal infection play a role in the FB x B. fabae interaction (Hanounik and Maliha, 1986; Hanounik and Robertson, 1988).

The rapid generation of hydrogen peroxide $\left(\mathrm{H}_{2} \mathrm{O}_{2}\right)$, one type of reactive oxygen species (ROS), has been considered as one of the earliest cellular responses in both compatible and incompatible plant $\times$ pathogen interactions (GarciaLimones et al., 2002; Mellersh et al., 2002). In the present study, a significant increase in $\mathrm{H}_{2} \mathrm{O}_{2}$ generation in both $\mathrm{FB}$ cultivars was observed in response to $B$. fabae inoculation, compared with un-inoculated plants. These results suggested that the induction of $\mathrm{H}_{2} \mathrm{O}_{2}$ in inoculated leaves may be one of the FB defense mechanisms against the invading necrotrophic pathogen. However, the greatest accumulation of $\mathrm{H}_{2} \mathrm{O}_{2}$ was detected in the susceptible cultivar Giza 40, indicating that the higher levels of ROS correlated with the susceptibility of FB leaf tissues to infection with $B$. fabae. Govrin and Levine (2000) showed that the inoculation of B. cinerea induced an oxidative burst in Arabidopsis, and the aggressiveness of this pathogen was directly dependent on the level of ROS accumulation. Additionally, Shi et al., (2011) found that the overexpression of transcription factor AtMYB44 in Arabidopsis resulted in stronger ROS formation, greater cell death and the facilitation of the $B$. cinerea infection process.

It is interesting that the oxidative burst generation profiles were different between the current FB cultivars. In the resistant tissues, the levels of $\mathrm{H}_{2} \mathrm{O}_{2}$ sharply accumulated and reached its maximum at $24 \mathrm{hpi}$, which was approximately double that recorded in susceptible tissues. Thereafter, a decline in the $\mathrm{H}_{2} \mathrm{O}_{2}$ content was noted. In contrast, $\mathrm{H}_{2} \mathrm{O}_{2}$ accumulation was stronger and more intense in the susceptible tissues in later stages of infection. Moreover, higher $\mathrm{H}_{2} \mathrm{O}_{2}$ concentrations contributed to the formation of restricted necrotic spots in the leaves of the resistant cultivar or expanding and water soaking areas in the leaves of the susceptible cultivar. Malolepsza and Urbanek (2000) showed that $B$. cinerea conidia were sensitive to $\mathrm{H}_{2} \mathrm{O}_{2}$, and higher concentrations of it inhibited fungal mycelial growth. They concluded that if the germination of $B$. cinerea conidia did not stop at the early infection stages, then high concentrations of $\mathrm{H}_{2} \mathrm{O}_{2}$ could not inhibit the mycelial growth inside the host tissues. Patykowski and Urbanek (2003) reported that the resistance of tomato plants against $B$. cinerea infection resulted from the early induction of $\mathrm{H}_{2} \mathrm{O}_{2}$. The same 
was observed for the interaction of tomato plants with Colletotrichum coccodes causing anthracnose (Mellersh et al., 2002), and Rhizoctonia solani causing tomato foot and root rot (Nikraftar et al., 2013). These observations suggest that the accumulation of $\mathrm{H}_{2} \mathrm{O}_{2}$ in the early stage of resistant $\mathrm{FB}$ cultivar Nubaria- $B$. fabae interaction is consistent with its role as an antimicrobial agent or it may function as a signal to trigger other defense responses (Asselbergh et al., 2007; Lamb and Dixon, 1997). At a later stage of disease development, higher intensive $\mathrm{H}_{2} \mathrm{O}_{2}$ levels caused destructive changes in the susceptible Giza 40 cultivar and facilitated the invasion and spread of necrotrophs in dead leaf tissues (von Tiedemann, 1997).

Excess ROS leads to the peroxidation of unsaturated lipids of membranes in plants (Apel and Hirt, 2004). MDA content, the secondary end product of lipid peroxidation, has been considered a biochemical indicator of oxidative damage (Heath and Packer, 1968). For the inoculated plants of both cultivars, there was a significant increase in MDA levels during the infection process of $B$. fabae compared with un-inoculated controls. The high levels of MDA indicated the induction of serious membrane damage in leaf tissues through free radical formation following infection (Govrin and Levine, 2000). The enhanced production of lipid peroxides has been shown in many plant $\mathrm{x}$ pathogen interactions (Chavan et al., 2013; Mandal et al., 2011). However, in this study, a positive relationship between the high rates of lipid peroxidation and disease development was found. The accumulation levels of MDA were higher in susceptible leaf tissues than in the resistant ones. These results may indicate that oxidative damage helps the necrotrophic pathogen $B$. fabae to overcome the plant defense system and aids in successful pathogenesis (Govrin and Levine, 2000).

Plants, however, possess an inherent capacity to eliminate the harmful effects of ROS through the involvement of an antioxidative system that protects cell constituents from the oxidative damage. SOD is the most effective intracellular enzyme in ROS metabolism and catalyzes the dismutation of $\mathrm{O}_{2}^{-}$to $\mathrm{H}_{2} \mathrm{O}_{2}$ (Gill and Tuteja, 2010). In the present study, SOD activity was shown to increase in FB leaves infected by $B$. fabea, but the activity for the resistant cultivar Nubaria was greater than that for the susceptible cultivar Giza 40. This result is in agreement with Debona et al. (2012), who demonstrated that the SOD activity was higher in leaves of wheat cultivar resistant to Pyricularia oryzae than in a susceptible cultivar. It was reported that necrotrophic pathogens, e.g., B. cinerea, induce ROS generation in plants and use these oxidative forces to attack, colonize and destroy host tissues (Asselbergh et al., 2007;
Govrin and Levine, 2000; Mandal et al., 2008; Nikraftar et al., 2013). Thus, higher SOD activity in the resistant cultivar Nubaria could be a strategy by which to restrict $B$. fabea spreading because the excess ROS can be removed (Ehsani-Moghaddam et al., 2006).

CAT is an important enzyme that protects the plant cells from oxidative damage by ROS (Gill and Tuteja, 2010). In this study, FB leaves (resistant and susceptible) inoculated with $B$. fabae demonstrated a significant increase of CAT activity compared with un-inoculated leaves. However, the induced levels of CAT were significantly higher in the inoculated leaves of the resistant cultivar compared to susceptible one. These differences in the activities between cultivars suggested that CAT plays a major role in FB resistance to chocolate spot. The low enzymatic activities in the susceptible leaf tissues have rendered them less efficient at reducing the high levels of $\mathrm{H}_{2} \mathrm{O}_{2}$ during the late stages of $B$. fabae infection. According to Mandal et al. (2008) a less efficient enzymatic ROS scavenging system, mainly a decrease in CAT activity, explains the high level of damage caused by F. oxysporum f. sp. lycopersici. Additionally, Debona et al. (2012) reported that the leaves of a resistant wheat cultivar infected with $P$. oryzae accumulated more CAT than did the susceptible cultivars.

APX is thought to play the most essential role in scavenging ROS and protecting cells in higher plants (Gill and Tuteja, 2010). Mandal et al. (2008) reported that the increased production of APX in tomato root inoculated with $F$. oxysporum counteracted the higher MDA and $\mathrm{H}_{2} \mathrm{O}_{2}$ levels and prevents oxidative damage of root tissues. Ge et al. (2014) observed an enhanced activity of APX in muskmelon plants inoculated with Colletotrichum lagenarium, and the level of APX activity was significantly higher in the resistant cultivar. Moreover, Nikraftar et al. (2013) found that the higher levels of APX were associated with the partial resistance of tomato plants to Rhizoctonia solani. These reports are in agreement with the data from the present study, which show that the APX activity was maintained at a higher level in the leaves of the resistant FB plants than in susceptible plants during $B$. fabea infection process.

Because PR proteins are a constituent of the plant defense strategy, their potential role in the defense against pathogens has been studied extensively in a several plants (Ebrahim et al., 2011). The $P R-1$ proteins, as well as other PRs, are well known markers for disease resistance and systemic acquired resistance against a pathogen attack (Hong et al., 2005; Mitsuhara et al., 2008). In the present study, the expression levels of the VfPRl gene were greater in inoculated leaves and higher in the resistant cultivar compared to the susceptible one, demonstrating that this gene is trig- 
gered in response to infection and that its induction contributes to the resistance against $B$. fabae. An increase in the expression level of this protein was reported in FB leaves infected with Uromyces fabae (Rauscher et al., 1999) and Puccinia striiformis f. sp. tritici (Cheng et al., 2012), and in tomato plants infected with Fusarium oxysporum f. sp. lycopersici (Aimé et al., 2008). Systemic resistance against B. cinerea in Arabidopsis plants triggered by an olive marc compost substrate was associated with increased levels of PR-1 (Segarra et al., 2013). Moreover, tobacco plants overexpressing pepper $P R-1$, were less susceptible to infection with Phytophthora nicotinae, Ralstonia solanacearum and Pseudomonas syringae (Sarowar et al., 2005).

After infection, the transcript profiles of VfPR 2 gene were differently expressed between susceptible and resistant cultivars. The response of the resistant cultivar Nubaria was earlier and stronger, showing high transcript levels after infection. The induction of this gene following infection with its known involvement in defending against fungi (van Loon et al., 2006), indicates that this gene might be involved in the FB resistance response against B. fabae. These results are in agreement with those showing a positive correlation between plant resistance and increased levels of $\beta$-1,3-glucanase (Aimé et al., 2008; Cota et al., 2007; Ebrahim et al., 2011). However, the earlier induction of VfPR2 gene in the resistant cultivar suggests the presence of mechanisms that ensure the earlier triggering of defense responses to $B$. fabae compared to the susceptible cultivar. Such an earlier induction of VfPR2 could be related to the early activity of the corresponding protein in releasing short $\beta$-1,3-glucan elicitors from pathogen, which are capable of further enhancing the induction of defense-related genes (Ebel and Cosio, 1994).

In conclusion, the levels of $\mathrm{H}_{2} \mathrm{O}_{2}$ and lipid peroxidation increased in both susceptible and resistant FB plants due to infection with a necrotrophic pathogen, but the increased levels in susceptible plants were more considerable (particularly in the later stages of infection). However, more efficient antioxidative system in the removal of the excess of ROS generated during the infectious process limits the cellular damage, coupled with earlier and higher expression of $P R$ genes transcripts in the infected resistant tissues compared to susceptible tissues may contribute to a greater resistance against chocolate spot. Therefore, the expression analyses of these defense responses could be used as biomarkers to predict the resistance to $B$. fabae in FB cultivars.

\section{Acknowledgment}

This study was supported by the Deanship of Scientific
Research, College of Food and Agriculture Sciences, Research Center, King Saud University.

\section{References}

Abo-Hegazy, S. R. E., El-Badawy, N. F., Mazen, M. M. and Abd El-Menem, H. 2012. Evaluation of Some faba bean genotypes against chocolate spot disease using cDNA fragments of chitinase gene and some traditional methods. Asian J. Agric. Res. 6:60-72.

Abou-Zeid, N. M., Moustafa, M. S. H., Hassanien, A. M. and Ez-El-Din, I. 1990. Control of chocolate spot disease of faba bean and the effect of fungicides on the behavior of the causal fungus. Agric. Res. Rev. 68:411-421.

Aimé, S., Cordier, C., Alabouvette, C. and Olivain, C. 2008. Comparative analysis of PR gene expression in tomato inoculated with virulent Fusarium oxysporum f. sp. lycopersici and the biocontrol strain F. oxysporum Fo47. Physiol. Mol. Plant Pathol. 73:9-15.

Apel, K. and Hirt, H. 2004. Reactive oxygen species: metabolism, oxidative stress, and signal transduction. Annu. Rev. Plant Biol. 55:373-399.

Asselbergh, B., Curvers, K., Franca, S. C., Audenaert, K., Vuylsteke, M., Breusegem, F. V. and Höfte, M. 2007. Resistance to Botrytis cinerea in sitiens, an abscisic acid-deficient tomato mutant, involves timely production of hydrogen peroxide and cell wall modifications in the epidermis. Plant Physiol. 144: $1863-1877$.

Attia, M. F., Abou-Zeid, N. M., Abada, K. A., Soliman, M. H. and El-Badawy, N. F. 2007. Isolation of chitinase gene induced during infection of Vicia faba by Botrytis fabae. Arab J. Biotech. 10:289-300.

Beauchamp, C. and Fridovich, I. 1971. Superoxide dismutase: improved assays and an assay applicable to acrylamide gels. Anal. Biochem. 44:276-286.

Bertini, L., Leonardi, L., Caporale, C., Tucci, M., Cascone, N., Di Berardino, I., Buonocore, V. and Caruso, C. 2003. Pathogen-responsive wheat PR4 genes are induced by activators of systemic acquired resistance and wounding. Plant Sci. 164:1067-1078.

Bolwell, P. G., Bindschedler, L. V., Blee, K. A., Butt, V. S., Davies, D. R., Gardner, S. L., Gerrish, C. and Minibayeva, F. 2002. The apoplastic oxidative burst in response to biotic stress in plants: a three component system. J. Exp. Bot. 53: 1367-1376.

Bouhassan, A., Sadiki, M. and Tivoli, B. 2004. Evaluation of a collection of faba bean (Vicia faba L.) genotypes originating from the Maghreb for resistance to chocolate spot (Botrytis fabae) by assessment in the field and laboratory. Euphytica 135:55-62.

Bradford, M. M. 1976. A rapid and sensitive method for the quantification of microgram quantities of protein utilizing the principle of protein-dye binding. Anal. Biochem. 72:11511154. 
Bradley, D. J., Kjellbom, P. and Lamb, C. J. 1992. Elicitor- and wound-induced oxidative crosslinking of a proline-rich plant cell wall protein; a novel, rapid defence response. Cell 70:2130.

Cakmak, I. and Marschner, H. 1992. Magnesium deficiency and high light intensity enhance activities of superoxide dismutase, ascorbate peroxidase and glutathione reductase in bean leaves. Plant Physiol. 98:1222-1227.

Chavan, V., Bhargava, S. and Kamble, A. 2013. Temporal modulation of oxidant and antioxidative responses in Brassica carinata during $\beta$-aminobutyric acid-induced resistance against Alternaria brassicae. Physiol. Mol. Plant Pathol. 83:35-39.

Cheng, Y., Zhang, H., Yao, J., Wang, X., Xu, J., Han, Q., Wei, G., Huang, L. and Kang, Z. 2012. Characterization of non-host resistance in broad bean to the wheat stripe rust pathogen. BMC Plant Biol. 12:96.

Cota, I. E., Troncoso-Rojas, R., Sotelo-Mundo, R., Sánchez-Estrada, A. and Tiznado-Hernández, M. E. 2007. Chitinase and $\beta$-1,3-glucanase enzymatic activities in response to infection by Alternaria alternata evaluated in two stages of development in different tomato fruit varieties. Sci. Hortic. 112:4250.

Dangl, J. and Jones, J. D. G. 2001. Plant pathogens and integrated defense responses to pathogens. Nature 411:826-834.

Debona, D., Rodrigues, F. Á., Rios, J. A. and Nascimento, K. J. T. 2012. Biochemical changes in the leaves of wheat plants infected by Pyricularia oryzae. Phytopathology 102:11211129.

Ebel, J. and Cosio, E. G. 1994. Elicitors of plant defense responses. Int. Rev. Cytol. 148:1-36.

Ebrahim, S., Ushaa, K. and Singh, B. 2011. Pathogenesis-related (PR) proteins: Chitinase and $\beta$-1,3-glucanase in defense mechanism against malformation in mango (Mangifera indica L.). Sci. Hortic. 130:847-852.

Ehsani-Moghaddam, B., Charles, M. T., Carisse, O. and Khanizadeh, S. 2006. Superoxide dismutase responses of strawberry cultivars to infection by Mycosphaerella fragariae. J. Plant Physiol. 163:147-153.

Garcia-Limones, C., Hervas, A., Navas-Cortes, J. A., JimenezDiaz, R. M. and Tena, M. M. 2002. Induction of an antioxidant enzyme system and other oxidative stress markers associated with compatible and incompatible interactions between chickpea (Cicer arietinum L.) and Fusarium oxysporum f. sp. ciceris. Physiol. Mol. Plant Pathol. 61:325-337.

Ge, Y., Guest, D. I. and Bi, Y. 2014. Differences in the Induction of defence responses in resistant and susceptible muskmelon plants infected with Colletotrichum lagenarium. J. Phytopathol. 162:48-54.

Gill, S. S. and Tuteja, N. 2010. Reactive oxygen species and antioxidant machinery in abiotic stress tolerance in crop plants. Plant Physiol. Biochem. 48:909-930.

Gomez, K. A. and Gomez, A. A. 1984. Statistical Procedures for Agricultural Research, 2nd edn. New York: John Wiley, 680pp.
Govrin, E. M. and Levine, A. 2000. The hypersensitive response facilitates plant infection by the necrotrophic pathogen Botrytis cinerea. Curr. Biol. 10:751-757.

Hanounik, S. B. and Maliha, N. 1986. Horizontal and vertical resistance in Vicia faba to chocolate spot caused by Botrytis fabae. Plant Dis. 70:770-773.

Hanounik, S. B. and Robertson, L. D. 1988. New sources of resistance in Vicia faba to chocolate spot caused by Botrytis fabae. Plant Dis. 72:696-698.

Heath, R. L. and Packer, L. 1968. Photoperoxidation in isolated chloroplasts. I. Kinetics and stoichiometry of fatty acid peroxidation. Arch. Biochem. Biophys. 125:189-198.

Hong, J. K., Lee, S. C. and Hwang, B. K. 2005. Activation of pepper basic PR-1 gene promoter during defense signaling to pathogen, abiotic and environmental stresses. Gene 356:169 -180 .

ICARDA, 1986. Screening Techniques for Disease Resistance in Faba bean. International Center for Agricultural Research in the Dry Areas, Aleppo, Syria, 59pp.

Khalil, S. A. and Harrison, J. G. 1981. Methods of evaluating faba bean materials for chocolate spot. FABIS Newsletter 3: 51-52.

Khalil, S. A., El-Hady, M. M., Dissouky, R. F., Amer, M. I. and Omar, S. A. 1993. Breeding for high yielding ability with improved level of resistance to chocolate spot (Botrytis fabae) disease in faba bean (Vicia faba). J. Agric. Sci. Mansoura Univ. 18:1315-1328.

Laloi, C., Apel, K. and Danon, A. 2004. Reactive oxygen signalling: the latest news. Curr. Opin. Plant Biol. 7:323-328.

Lamb, C. and Dixon, R. A. 1997. The oxidative burst in plant disease resistance. Annu. Rev. Plant Physiol. Plant Mol. Biol. 48:251-275.

Leach, R. and Moore, K. G. 1966. Sporulation of Botrytis fabae on agar culture. T. Brit. Mycol. Soc. 49:593-601.

Malolepsza, U. and Urbanek, H. 2000. The oxidants and antioxidant enzymes in tomato leaves treated with $o$-hydroxyethylorutin and infected with Botrytis cinerea. Eur. J. Plant Pathol. 106:657-665.

Mandal, S., Das, R. K. and Mishra, S. 2011. Differential occurrence of oxidative burst and antioxidative mechanism in compatible and incompatible interactions of Solanum lycopersicum and Ralstonia solanacearum. Plant Physiol. Biochem. 49:117-123.

Mandal, S., Mitra, A. and Mallick, N. 2008. Biochemical characterization of oxidative burst during interaction between Solanum lycopersicum and Fusarium oxysporum f. sp. lycopersici. Physiol. Mol. Plant Pathol. 72:56-61.

Mauch, F., Mauch-Mani, B. and Boller, T. 1988. Antifungal hydrolases in pea tissues. II. Inhibition of fungal growth by combinations of chitinase and $\beta$-1,3-glucanase. Plant Physiol. 88:936-942.

Mayer, A. M., Staples, R. C. and Gil-ad, N. L. 2001. Mechanisms of survival of necrotrophic fungal plant pathogens in hosts expressing the hypersensitive response. Phytochemistry 58: 
33-41.

Mellersh, D. G., Foulds, I.V ., Higgins, V. J. and Heath, M. C. 2002. $\mathrm{H}_{2} \mathrm{O}_{2}$ plays different roles in determining penetration failure in three diverse plant-fungal interactions. Plant J. 29: 257-268.

Mitsuhara, I., Iwai, T. Seo, S., Yanagawa, Y., Kawahigasi, H., Hirose, S., Ohkawa, Y. and Ohashi, Y. 2008. Characteristic expression of twelve rice PR1 family genes in response to pathogen infection, wounding, and defense-related signal compounds (121/180). Mol. Genet. Genomics 279:415-427.

Mittler, R. 2002. Oxidative stress, antioxidants and stress tolerance. Trends Plant Sci. 7:405-410.

Nakano, Y. and Asada, K. 2001. Hydrogen peroxide is scavenged by ascorbate-specific peroxidase in spinach chloroplasts. Plant Cell Physiol. 22:867-880.

Nikraftar, F., Taheri, P., Rastegar, M. F. and Tarighi, S. 2013. Tomato partial resistance to Rhizoctonia solani involves antioxidative defense mechanisms. Physiol. Mol. Plant Pathol. 81: 74-83.

Park, C. J., An, J. M., Shin, Y. C., Kim, K. J., Lee, B. J. and Peak, K. H. 2004. Molecular characterization of pepper germin-like protein as the novel PR-16 family of pathogenesis-related proteins isolated during resistance response to viral and bacterial infection. Planta 219:797-806.

Patykowski, J. and Urbanek, H., 2003. Activity of enzymes related to $\mathrm{H}_{2} \mathrm{O}_{2}$ generation and metabolism in leaf apoplastic fraction of tomato leaves infected with Botrytis cinerea. $J$. Phytopathol. 151:153-161.

Peng, M. and Kuć, J. 1992. Peroxidase-generated hydrogen peroxide as a source of antifungal activity in vitro and on tobacco leaf discs. Phytopathology 82:696-699.

Rauscher, M., Adam, A. L., Wirtz, S., Guggenheim, R., Mendgen, K. and Deising, H. B. 1999. PR-1 protein inhibits the differentiation of rust infection hyphae in leaves of acquired resistant broad bean. Plant J. 19:625-633.

Rhaïem, A., Cherif, M., Kharrat, M., Cherif, M. and Harrabi, M. 2002. New faba bean genotypes resistant to chocolate spot caused by Botrytis fabae. Phytopathol. Mediterr. 41:99-108.

Sarowar, S., Kim, Y. J., Kim, E. N., Kim, K. D. and Hwang, B. K. 2005. Overexpression of a pepper basic pathogenesis-related protein 1 gene in tobacco plants enhances resistance to heavy metal and pathogen stresses. Plant Cell Rep. 24:216-224.

SAS Institute Inc., 2003. SAS/STATA Guide for Personal Computers Version 9.1 edition. SAS Institute, Carry NC, USA.

Segarra, G., Elena, G. and Trillas, I. 2013. Systemic resistance against Botrytis cinerea in Arabidopsis triggered by an olive marc compost substrate requires functional SA signaling. Physiol. Mol. Plant Pathol. 82:46-50.

Shaner, G. and Finney, R. E. 1977. The effect of nitrogen fertilization on the expression of slow mildewing resistance in knox wheat. Phytopathology 67:1051-1056.

Shi, H., Cui, R., Hu, B., Wang, X., Zhang, S., Liu, R. and Dong, H. 2011. Overexpression of transcription factor AtMYB44 facilitates Botrytis infectionin Arabidopsis. Physiol. Mol. Plant Pathol. 76:90-95.

Sillero, J. C., Villegas-Fernández, A. M., Thomas, J., RojasMolina, M. M., Emeran, A. A., Fernández-Aparicio, M. and Rubiales, D. 2010. Faba bean breeding for disease resistance. Field Crops Res. 115:297-307.

Torres, A. M., Roman, B., Avila, C. M., Satovic, Z., Rubiales, D., Sillero, J. C., Cubero, J. I. and Moreno, M. T. 2004. Faba bean breeding for resistance against biotic stresses, towards application of marker technology. Euphytica 147:67-80.

Unger, C., Kleta, S., Jandl, G. and von Tiedemann, A. 2005. Suppression of the defence related oxidative burst in bean leaf tissue and bean suspension cells by the necrotrophic pathogen Botrytis cinerea. J. Phytopathol. 153:15-26.

van Loon, L. C. 1997. Induced resistance in plants and the role of pathogenesis-related proteins. Eur. J. Plant Pathol. 103:753765.

van Loon, L. C. and Van Strien, E. A. 1999. The families of pathogenesis-related proteins, their activities, and comparative analysis of PR-1 proteins. Physiol. Mol. Plant Pathol. 55: $85-97$.

van Loon, L. C., Rep, M. and Pieterse, C. M. J. 2006. Significance of inducible defense-related proteins in infected plants. Annu. Rev. Phytopathol. 44:135-162.

Velikova, V., Yordanov, I. and Edreva, A. 2000. Oxidative stress and some antioxidant systems in acid rain treated bean plants: protective role of exogenous polyamines. Plant Sci. 151:5966.

Villegas-Fernández, A. M., Sillero, J. C., Emeran, A. A., Winkler, J., Raffiot, B., Tay, J., Flores, F. and Rubiales, D. 2010. Identification and multi-environment validation of resistance to Botrytis fabae in Vicia faba. Field Crops Res. 114:84-90.

von Tiedemann, A. 1997. Evidence for a primary role of oxygen species in induction of host cell death during infection of bean leaves with Botrytis cinerea. Physiol. Mol. Plant Pathol. 50:151-166. 